\title{
South African agency faces new priorities
}

Cape Town. F. W. de Klerk, president of South Africa, and Nelson Mandela, president of the African National Congress (ANC), last week agreed terms for a draft constitution, clearing the way for South Africa's first open elections. For institutions such as the Council for Scientific and Industrial Research (CSIR), the main channel of government funds for applied research, next year's election results are awaited with some trepidation.

The CSIR performed well in a recent ANC review of science and technology institutions. But it is undergoing a period of evolution and uncertainty that began with a restructuring in 1988. The council is changing its focus from pure and applied research to research orientated specifically towards technology and its development.

In the 1980 s, South Africa had a lucrative market in defence and other strategic industries. Government spending on research and development has, however, since dropped from 0.82 per cent to only 0.55 per cent of the federal budget. After next year's election, the government's spending priorities will almost certainly be different.

Brian Clark, the president of CSIR, believes the council's focus will remain on technology, and sees this being directed towards three goals: making South African industry more competitive in international markets; promoting local development; and assisting in government decision-making, for example through advising on the environmental impact of new developments.

Between 1988 and 1993, the new CSIR had its parliamentary grant increased by only 7 per cent, from R192 million (US\$45 million) to R205 million, well behind inflation. As a result, government funding has now dropped from 55.5 to 46 per cent of the council's income. The balance is made up of income derived from research contracts and investments and royalties from patents. The former has risen from 35 to 46.5 per cent exceeding the parliamentary grant for the first time last year.

The council has had increasing success in attracting foreign funds, as well as support from the private sector. Six per cent of its contract income last year came from abroad, compared with one per cent in 1988 .

In contrast, research contracts from both the civil public sector and the defence industry have dropped sharply and are expected to fall further this year. There is a question over whether the CSIR can continue to increase its income from the private and foreign sectors, and whether it can hold onto its parliamentary grant.

This year, the council's grant was increased by 16 per cent - the first increase in real terms since its restructuring. The decision prompted speculation that it was being 'bailed out' by government. But Clark denies this, explaining that most of the new money was part of a special allocation earmarked by the state for additional employer contributions to the CSIR's pension fund.

The council fared better than many other bodies in a review of South Africa's science

\section{Mandela backs science park plan}

Cape Town. Africa's largest research and manufacturing park is to be built on a site in Cape Town. The first construction phase is due to begin in October next year, six months after the country's first democratic elections.

The science complex, to be known as Capricorn Park, is being developed by the British company Science Research Parks Limited, at an estimated cost of R1 billion (US $\$ 230$ million). It is expected eventually to provide jobs for 40,000 people at 32 industrial and research sites.

Nelson Mandela, president of the African National Congress, has already thrown his weight behind the project. Addressing the Confederation of British Industry in London last month, he said the park "should contribute significantly to science and technology development" in South Africa.

The goal of the developers is to provide international high-technology manufacturing companies with an opportunity to invest in South Africa now that economic sanctions against the country have been lifted.
Supporters of the planned park claim that the Western Cape - one of nine regions proposed in the new federal constitution - could become the 'Silicon Valley' of Africa, with its relatively highly skilled workforce and its pleasant climate and surroundings.

The region's three universities and two technical institutions (technikons) will participate in activities at the park through the Cape Science Foundation. The park will place a strong emphasis on training programmes and an academic centre will form the central focus of the site.

South Africa has virtually no domestic tradition of privately financed research and development, and the success of the project will therefore hinge on whether international companies are attracted by investment opportunities under the new government. The region already has a 'technopark' in Stellenbosch, less than 30 miles from Cape Town. But only three of its 41 sites have been developed, and a further seven sold, since it was founded eight years ago. M. C. and technology system compiled for the ANC (see Nature 362, 384; 1993). However, the review criticized the council's emphasis on meeting the needs of big business, pointing out that only a third of CSIR contract income is derived from small and medium-sized companies.

In response, the CSIR has launched a special initiative in technology transfer to these smaller enterprises. But some scientists still feel that the council is not much more than a giant consultancy, and as such has no real claim to a state subsidy.

Jennifer Thomson and Johan Lutjeharms, two former CSIR employees who now hold chairs at the University of Cape Town, claimed earlier this year in the South African Journal of Science that "science as a thriving, innovative, intellectual enterprise within the CSIR is dead".

Certainly, the number of publications produced by CSIR employees has declined from more than 300 in 1988 to fewer than 100 last year.

But in the same issue of the journal, CSIR's vice-president, Daan Toerien, argued that, in the context of its new mission, it was more relevant that the number of patent applications filed by the CSIR had trebled over the same period.

Anastassios Pouris, newly appointed director of science and technology policy at the Foundation for Research Development says there is still a great deal of confusion. "The problem with the present science system is that the taxpayer doesn't know whether he is subsidizing research for the private sector, basic research, strategic research, routine testing or even, in some cases, just enabling councils to compete favourably with private consultancies."

Questions have also been raised about the CSIR's continued close links with the military: the South African Air Force recently rejected the purchase of the 'Ovid' aircraft, developed locally with the CSIR, in favour of the Swiss 'Pilatus'.

But Clark denies that the CSIR is tainted by such links. "At an executive level we have a very good open relationship with the democratic movement", he says, adding that what is required is "transparency and openness, not the secrecy of the past".

The main issue facing the CSIR is whether the promotion of technological research and development (R\&D) is best achieved by investing state funds in a research council. But in the short term there may be little alternative. There is very little in-house $R \& D$ being undertaken by the private sector in South Africa. Nor is there any comprehensive incentive scheme by which R\&D spending can be written off against tax, a procedure that some feel could be a better way of promoting technological development.

Michael Cherry 